al-Ihkam: Jurnal Hukum dan Pranata Sosial, 16 (2), 2021: 393-420

ISSN: 1907-591X, E-ISSN: 2442-3084

DOI: http://doi.org/10.19105/al-lhkam.v16i2.4817

\title{
Meta-Analysis at the Root of Terrorism from the Perspective of Islamic Movement in Indonesia
}

\author{
Dinda Rosanti Salsa Bela \\ Department of Government Affairs and Administration, Jusuf Kalla School of \\ Government, Universitas Muhammadiyah Yogyakarta, Yogyakarta, Indonesia \\ Email: dindarosantisalsabela@gmail.com \\ Achmad Nurmandi \\ Department of Government Affairs and Administration, Jusuf Kalla School of \\ Government, Universitas Muhammadiyah Yogyakarta, Yogyakarta, Indonesia \\ Email:nurmandi_achmad@umy.ac.id \\ Isnaini Muallidin \\ Department of Government Affairs and Administration, Jusuf Kalla School of \\ Government, Universitas Muhammadiyah Yogyakarta, Yogyakarta, Indonesia \\ Email: muallidin@umy.ac.id \\ Danang Kurniawan \\ Department of Government Affairs and Administration, Jusuf Kalla School of \\ Government, Universitas Muhammadiyah Yogyakarta, Yogyakarta, Indonesia \\ Email: kurniawand949@gmail.com
}

Article history: Received: June 30, 2021, Accepted: December 21, 2021,

Published: December 27, 2021

\begin{abstract}
:
This paper aims to map the root of terrorism in Indonesia from the Islamic movement perspective. The authors want to know how the root of terrorism has strengthened in Indonesia. A qualitative method approach was taken through a literature study regarding the delivery of research map information while the data was exported in the RIS Export file format. Then, the authors exported the data and processed it using VOSviewer to find out a bibliometric map of research development based on significant themes of Indonesian
\end{abstract} Author correspondence email: dindarosantisalsabela@gmail.com Available online at: http:/ / ejournal.iainmadura.ac.id/index.php/alihkam/ Copyright (c) 2021 by al-ihkam. All Right Reserved 
terrorism cases. Nvivo 12 plus provided exploration and description of terrorism in Indonesia to get an efficient explanation of the data. The findings are, the first to map the issue of terrorism in Indonesia. First, there was a correlation between terrorism, radicalism, and Islam. Different views of religious teachings eventually led to the terrorism movement. Several radical Islamic organizations in Indonesia have portrayed Islam as a terrorist religion. Second, the factors causing the strengthening of terrorism in Indonesia were due to injustice, oppression, and discrimination leading to terrorism and radicalism using the concept of jihad. This research suggests that the government can handle terrorism cases in Indonesia and neutralize ideas that are considered radical with a de-radicalization approach.

\title{
Keywords:
}

Terrorism; Islamism; Indonesia

\begin{abstract}
:
Tulisan ini bertujuan memetakan akar terorisme di Indonesia dari aspek gerakan Islam. Penulis ingin mengetahui bagaimana akar terorisme menguat di Indonesia. Pendekatan metode kualitatif ditempuh melalui studi pustaka sedangkan untuk penyampaian informasi peta penelitian, data diekspor dalam format file Ekspor RIS. Kemudian, penulis mengekspor data dalam format (RIS), mengolahnya menggunakan VOS viewer untuk mengetahui peta bibliometrik pengembangan penelitian berdasarkan tema signifikan kasus terorisme di Indonesia dan menggunakan Nvivo 12 plus untuk memberikan eksplorasi dan deskripsi terorisme di Indonesia demi mendapatkan penjelasan yang efisien dari data. Temuan penelitian ini adalah; Pertama, pada tahap pemetaan isu terorisme di Indonesia, terdapat korelasi antara terorisme, radikalisme, dan Islam. Perbedaan pandangan terhadap ajaran agama pada akhirnya memunculkan gerakan terorisme. Beberapa organisasi Islam radikal di Indonesia telah mencitrakan Islam sebagai agama teroris. Kedua, diketahui faktor penyebab menguatnya terorisme di Indonesia adalah rasa ketidakadilan, penindasan dan diskriminasi yang berujung pada gerakan terorisme dan radikalisme dengan mengusung konsep jihad.
\end{abstract}


Saran dari penelitian ini adalah agar pemerintah dapat menangani kasus terorisme di Indonesia dan menetralisir ideide yang dianggap radikal dengan pendekatan deradikalisasi.

\section{Keywords:}

Terorisme; Islamisme; Indonesia

\section{Introduction}

Terrorism is increasingly becoming a scourge for modern civilization. ${ }^{1}$ The nature of actions, actors, objectives, motivations, expected and achieved results, targets, and methods of terrorism are now increasingly broad and varied. ${ }^{2}$ This research aims to map terrorism in Indonesia from the Islamic movement perspective. Furthermore, the authors want to know how terrorism can be stronger $\mathrm{n}$ Indonesia. In contrast to war, acts of terrorism are not subject to war procedures, such as the execution time which is always sudden, and the victim which is typically random and coming from civilians. ${ }^{3}$ The act of terrorism also implies that terrorist attacks carried out are inhumane and have no justification and therefore the perpetrators of "terrorists" deserve cruel retribution. ${ }^{4}$

The problem of terrorism requires broad and simultaneous handling in the fabric of close cooperation between the state, religions, and all components of society. ${ }^{5}$ Each has an important role and needs to

1 Firmansyah Firmansyah and Arief Hidayat, "Pendekatan Advokasi Muhammadiyah Dalam Penanganan Terorisme Di Indonesia," Journal of Political Issues 2, no. 1 (2020): 10-20.

2 Ahmad Rizky Mardhatillah Umar, "Melacak Akar Radikalisme Islam Di Indonesia," Jurnal Ilmu Sosial dan Ilmu Politik 14, no. 2 (2010): 169-186, https://jurnal.ugm.ac.id/jsp/article/view/10935.

3 Siti Ruhaini Dzuhayatin, "Islamism and Nationalism among Niqabis Women in Egypt and Indonesia," Indonesian Journal of Islam and Muslim Societies 10, no. 1 (2020): 49-77.

4 Reni Windiani, "Peran Indonesia Dalam Memerangi Terorisme," Jurnal Ilmu Sosial 16, no. 2 (2018): 135.

${ }^{5}$ Nurul Faiqah and Toni Pransiska, "Islamic Radicalism Vs Islamic Moderation: Efforts to Build the Face of Peaceful Indonesian Islam," Al-Fikra: Jurnal Ilmiah Keislaman 17, no. 1 (2018): 33-60, http://ejournal.uin-suska.ac.id/index.php/alfikra/article/view/5212. 
fulfill in a persuasive, educative, and transformative manner. ${ }^{6}$ The government, for instance, needs to acknowledge its role and responsibility to protect all citizens and create a sense of security and peace. ${ }^{7}$ Along with that, law enforcement is a must that every citizen has the same access to justice. ${ }^{8}$ A wrongdoer should receive a fair punishment. Besides, legal justice needs to be accompanied by welfare or equitable distribution of interest ${ }^{9}$. The absence of prosperity can lead to social movements with violent means and actions in demanding for justice.$^{10}$

Indonesia is still prone of terrorism action because the terror perpetrators are well-organized in society. ${ }^{11}$ By spreading terrorist members and remaining in one-way command, it is difficult for both public and the police to track them down. ${ }^{12}$ Here, the perpetrators of terrorism are misguided because they feel innocent with what they do like killing people, committing suicide, injuring others, and spreading false knowledge or belief. ${ }^{13}$.According to them, they do the right thing and follow the order. ${ }^{14}$ Although the activities or actions also harmed

\footnotetext{
${ }^{6}$ M. Affan, "The Threat of Is Proxy Warfare on Indonesian Millennial Muslims," Indonesian Journal of Islam and Muslim Societies 8, no. 2 (2018): 199-224.

7 Aria Nakissa, "Security, Islam, and Indonesia An Anthropological Analysis of Indonesiaâs National Counterterrorism Agency," Bijdragen tot de Taal-, Land- en Volkenkunde 176, no. 2-3 (2020): 203-239.

8 Ilyas Mohammed, "De-Radicalisation and Humanitarianism in Indonesia," Social Sciences 10, no. 3 (2021): 1-17.

9 Anastasia Yuni Widyaningrum and Noveina Silviyani Dugis, "Terorisme Radikalisme Dan Identitas Keindonesiaan," Jurnal Studi Komunikasi (Indonesian Journal of Communications Studies) 2, no. 1 (2018): 32-67.

10 Sekolah Tinggi et al., “Jurnalis Dan Terorisme ( Studi Pustaka Etika Jurnalis Dalam Meliput Dan Memberitakan Kasus Terorisme Di Media Siber )” 1, no. c (2020).

11 A S Mufid, "Radikalisme Dan Terorisme Agama, Sebab Dan Upaya $\begin{array}{llllll}\text { Pencegahan," Harmoni } 12, \quad \text { no. } & 1 & \text { (2013): }\end{array}$ https://jurnalharmoni.kemenag.go.id/index.php/harmoni/article/view/190.

12 Muchamad Sholakhuddin Al Fajri, "The Construction of Indonesian Muslims and Islam in Australian Newspapers: A Corpus-Assisted Critical Discourse Analysis," Discourse and Interaction 13, no. 1 (2020): 5-24.

13 Sidratahta Mukhtar, "Strategi Pemerintah Indonesia Menghadapi Terorisme Dalam Era Demokratisasi," Jurnal Reformasi 6, no. 2 (2016): 143-153.

14 Faiqah and Pransiska, "Islamic Radicalism Vs Islamic Moderation: Efforts to Build the Face of Peaceful Indonesian Islam."
} 
many parties, they typically have no willingness to stop their actions or correct themselves for what they had done. ${ }^{15}$

Indonesia has been facing an internal security crisis marked by the emergence of terrorism movements that the anti-ideological spirit of Pancasila (nation's five basic pillars), The State of Republic Indonesia (NKRI), and Bhinneka Tunggal Ika is the motto of the Indonesian nation which is written on the symbol of the Indonesian state. ${ }^{16}$ The threat of terrorism in Indonesia is real, even though only a Muslim minority is radicalized and deciding to do the violence. ${ }^{17}$ When terror in Indonesia occurs in a row followed by the arrest of terrorists based on the testimonies and networks formed by the perpetrators, at the same time, many people have dedicated their lives to becoming terrorists. Some others galvanize future terrorists, teach the science of terrorism, and convince people to follow.

Various studies and researches were conducted to explore the factors behind acts of terrorism that have emerged in almost all parts of the world. ome intellectuals and researchers have concluded that the trigger for terrorism is ideology or religion. ${ }^{18}$ In this case, the radical Islamic movement is often accused of being the trigger as well as the perpetrator of various acts of terror. ${ }^{19}$ Specifically in Indonesia, acts of terror or terrorist activities associated with Islam have shocked the world because most of Indonesia's population, approximately $87 \%$, is Muslim. ${ }^{20}$

15 (Mahfud et al., 2018)

16 Nakissa, "Security, Islam, and Indonesia An Anthropological Analysis of Indonesiaâs National Counterterrorism Agency."

17 G Yumitro et al., "The Modalities and Roles of Local Governments to Face Terrorism Issues in Indonesia: The Case Study of Malang Raya Region ," Revista UNISCI 2020, no. 53 (2020): 9-21, https://www.scopus.com/inward/record.uri?eid=2-s2.085087831775\&doi=10.31439\%2FUNISCI80\&partnerID $=40 \& m d 5=943 c 5405 d 2 e e 062184 a 5 d 43 c 071 b 48 f 4$.

18 (Hatta et al., 2019)

19 Mohammed Ilyas, “Decolonising the Terrorism Industry: Indonesia," Social Sciences 10, no. 2 (2021): 1-16.

20 S Priyanto, M K Dermawan, and A J S Runturambi, "Islah as the Key Success of Terrorist Disengagement Process in Indonesia," Journal of Al-Tamaddun 15, no. 1 (2020): 157-168, https://www.scopus.com/inward/record.uri?eid=2-s2.085090700861\&doi=10.22452\%2FJAT.vol15no1.11\&partnerID=40\&md5=aceff3c3f769ce 5bfeca9244a7decdc5. 
Indonesia, initially referred to as the concentration of calm and peaceful Muslims, was suddenly touched by the spread of terrorism. ${ }^{21}$ The connection between Indonesian jihadist fighters and other foreign jihadists leads to Al Qaeda and Jemaah Islamiah's broader relationship and network. ${ }^{22}$ The close relationship with international terrorism networks then becomes inevitable. ${ }^{23}$ Furthermore, the limited quality and capacity of intelligence institutions in handling terrorism make it hard to reveal the perpetrators and motives behind terrorism and the root of the problems. ${ }^{24}$ As a consequence, several acts of terrorism in Indonesia have not been fully disclosed by Indonesia's security forces. ${ }^{25}$ Therefore, this study seeks to answer the substantive questions: How is the mapping of terrorism in Indonesia from the Islamic movement's side?; How can terrorism be multiplied and stronger in Indonesia?

\section{Method}

Related to the purpose of this research to analyze terrorism cases in Indonesia and counter-terrorism by the government during the last five years, a literature review is considered as an appropriate research method. This research's data source comes from internationally accredited articles while data collection was done by searching through the database of Scopus at https://www.scopus.com/. Scopus is one of the most extensive citations and abstract databases of the reviewed literature such as scientific journals, books, and conference proceedings.

Search for articles through the https://www.scopus.com/ site by selecting several terms by ticking the access button "show open access journals" and depository institutions through the search column "Search for documents".For keywords in the Scopus search column, it is written as (TITLE-ABS-KEY ((TERRORISM and

21 Zulkhaidir Zulkhaidir, "Islam Dan Terorisme," Jurnal Ilmiah Islam Futura 7, no. 2 (2018): 49.

22 Agus Handoko, "Analisis Kejahatan Terorisme Berkedok Agama," SALAM: Jurnal Sosial dan Budaya Syar-i 6, no. 2 (2019): 155-178.

23 (Sahrasad et al., 2020)

${ }^{24}$ Mukhtar, "Strategi Pemerintah Indonesia Menghadapi Terorisme Dalam Era Demokratisasi."

25 Imam Mustofa, “TERORISME: ANTARA AKSI DAN REAKSI (Gerakan Islam Radikal Sebagai Respon Terhadap Imperealisme Modern)," Religia 15, no. 1 (2017). 
INDONESIA))) AND (LIMIT-TO (SUBJAREA, "SOCI")) AND (LIMITTO (OA), "all"))). Some of the data were analyzed descriptively based on the year of publication, the publishing institution, the issuing countries, the name of the journal/publication, the type of document, and the research topic.

Later on, for delivering research map information, the data is exported in the Export RIS file format. In the first discussion, the authors processed the data using VOSviewer to find out the bibliometric map of research development based on the big theme of terrorism cases in Indonesia. This means observing the frequency of words in the discussion as well as visualizing the relationship between the main themes and the most recent literature. In the second discussion, the authors processed data using Nvivo 12 for exploring and describing terrorism in Indonesia to explain the data efficiently.

\section{Discussion and Result}

\section{A. Indonesian Terrorism Case and Its Academic Trends}

Another factor that makes terrorism action in Indonesia gets increased is the use of high technology ${ }^{26}$ which makes it far easier to commit the action. Unsurprisingly, despite the ups and downs, the record shows that terrorism does exist in the country as clear the graph 1 ;

${ }^{26}$ S R Dzuhayatin, "Islamism and Nationalism among Niqabis Women in Egypt and Indonesia," Indonesian Journal of Islam and Muslim Societies 10, no. 1 (2020): 49-77, https://www.scopus.com/inward/record.uri?eid=2-s2.085086372317\&doi=10.18326\%2Fijims.v10i1.49-

77\&partnerID=40\&md5=afe1d4cd4042018624cb86a852d450ae. 


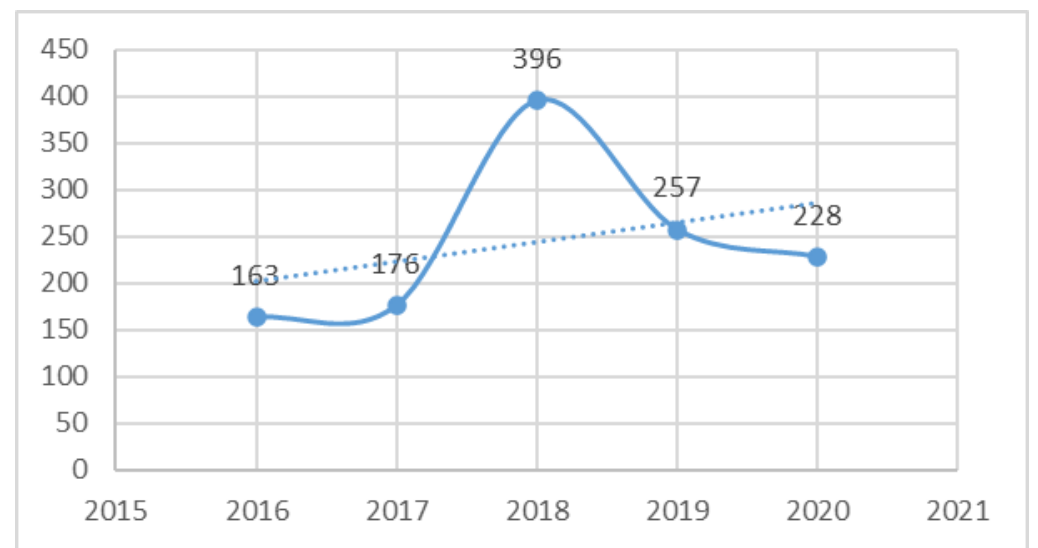

Graph 1. Number of Terrorism Cases in Indonesia (source by https://www.scopus.com/)

As a result, Indonesia is considered a dangerous country. Indonesia, which was once a friendly population, has now become a country whose inhabitants are considered dangerous to other nations. ${ }^{27}$ In this context, Indonesian identity is at stake. The millions of innocent Indonesian people who are not involved in terrorism activities share the consequences of radicalism accusations leading to terrorism carried out by relatively small certain groups. ${ }^{28}$

Indonesian terrorism has a comprehensive and global network that threatens national peace and security. As a country with the largest Muslim population globally, Indonesia continues to be a part of the international conversation with ongoing events related to radicalism and terrorism. Starting with the Bali Bombings incident that intentionally sent a message to the international community about sentiment towards the United States, the event became a success with various following bombings in Jakarta and the Bali Bombing II. Such events with the background of radicalism made Indonesia one of the centers of world attention. ${ }^{29}$

The development of terrorism cases in Indonesia from 2016 to 2020 gets much attention among researchers as can be seen from the percentage of academic discussion themes. The figure below shows

27 (Mahfud et al., 2018)

28 Sahrasad et al., "Indonesian Terrorism: Wahabism and the 'Imagined Caliphate.'"

${ }^{29}$ Hatta et al., "The Impact of Terrorism on Indonesia's Economic Stability." 
that terrorism is the most frequently indicated thing in the literature with a percentage of $17 \%$. In this regard, religious points are also topics related to terrorism with a percentage of $12 \%$. Then other things related to Indonesia, media, radicals, the state, education, Islam, and issues have an average percentage below $10 \%$. All of these topics are certainly interrelated and influence each other with the strengthening of terrorism cases that occur in the Chart 1.

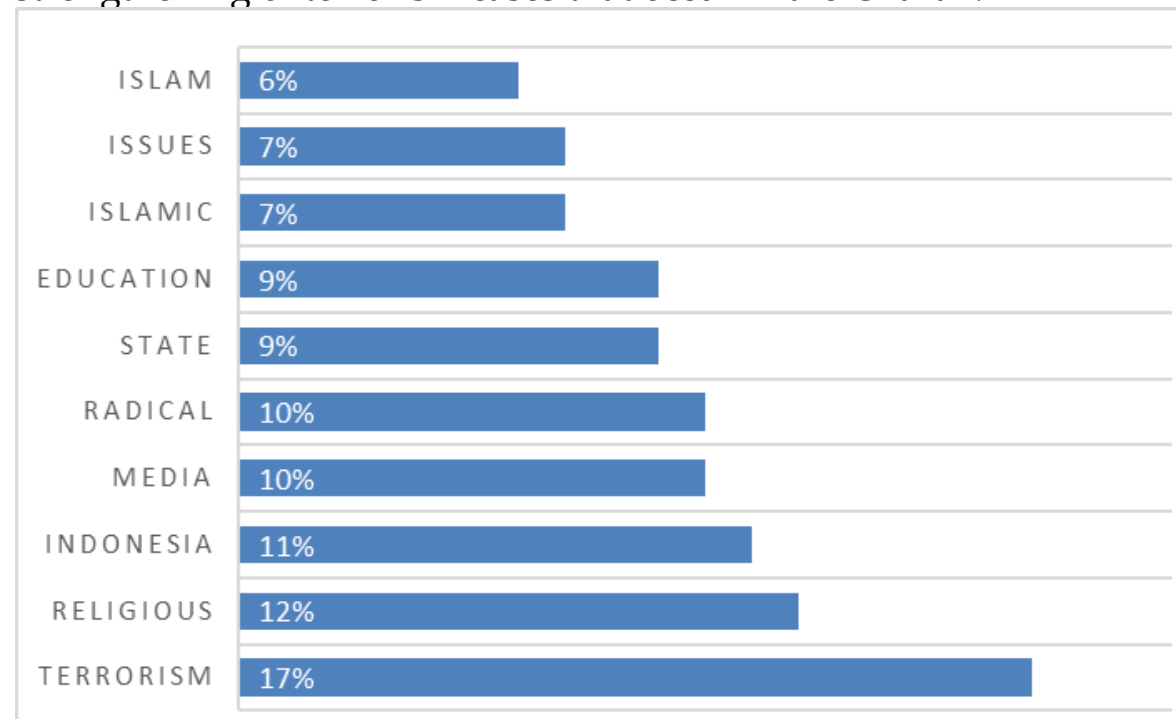

\section{Chart 1. Literature Analysis Based on (Discussion Theme) Terrorism Issues \\ (source by https://www.scopus.com/)}

The literature analysis in chart 1 shows that terrorism becomes an essential item. Terrorism cases certainly have a strong relationship with religious matters, namely Islam. The ideas considered radical have also had something to do with the Muslim community as the most Indonesia's population. ${ }^{30}$ In a pluralistic society where conflicts of interest are constant, democratic values become the hope for peaceful conflict resolution. In the name of democracy, every human being should ideally get recognition and respect for himself. ${ }^{31}$

\footnotetext{
${ }^{30}$ Windiani, "Peran Indonesia Dalam Memerangi Terorisme."

31 Muhaimin Zulhair Achsin, "Culture and Role of Woman in Terrorism in Indonesia. Case Studies: Suicide Bombings in Surabaya and Sibolga," International Journal of Engineering and Advanced Technology 8, no. 5 (2019): 873-876.
} 
Following the last five year record of Indonesian terrorism, the development of research on terrorism cases in Indonesia also experienced a growth trend with fluctuating dynamics as shown at the Graph 2 below;

Documents by year

Scopus

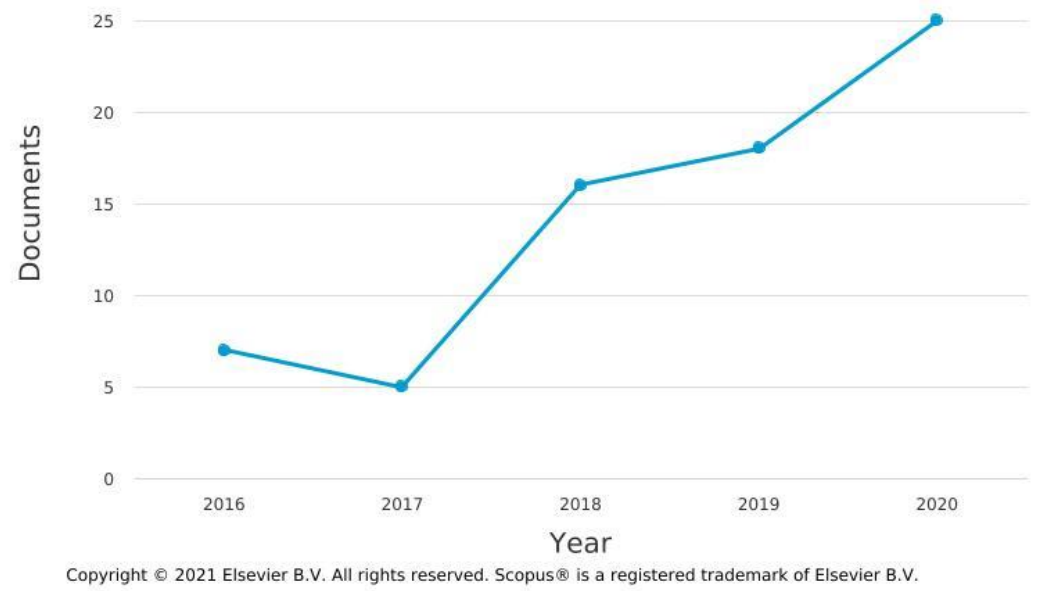

Graph 2. Trends of Terrorism Issues Research in Indonesia

Graph 2 shows the trend of annual publications related to terrorism cases occurring in Indonesia. In this study, the data were taken from 2016 to 2020. The number of detected data was 73 documents in which the authors selected 51 samples of it based on social science studies clustering. There are five documents in 2016, 2 in 2017, 11 in 2018, 13 in 2019, 16 for 2020, and 2 for 2021. From the graph 2 result a literature analysis based on the theme that processed data from 51 literature documents using Nvivo12 Plus.

\section{B. The Root of Terrorism Act in Indonesia}

Democracy is often identified with freedom of expression. On the other hand, freedom of self-expression and the right of every human being has become the key theme in the debate on the practice of radicalism growing at various societal levels. The method of radicalism is then considered the same as a form of self-expression as a part of human rights. When every individual and group has found a 
space for expression, the notion of radicalism begins to enter and be played by some actors with specific interests.

Terrorism, on the other hand, is essentially an act contradictory to the principles of human life whose emergence is often due to injustice among society and the lack of understanding of the scriptures as the basis of legal law in religion. ${ }^{32}$ Having that kind of seed, terrorism organizations commonly develop massively with the background of specific groups' interests and the legalization of superpower countries such as the United States and Israel to expand their wings of power or interests. ${ }^{33}$

Due to the negative meanings of "terrorist" and "terrorism," terrorists generally refer to themselves as separatists, liberation fighters, militants, mujahideen, and others. ${ }^{34}$ When they get caught either alive or killed, they often relate their struggle with jihad fi sabilillah teaching although, in a deeper analysis, their actions do not reflect religious teachings' values, especially Islam. ${ }^{35}$ In the Qur'an. For example, there is no commandment to kill a man unless the person commits a considerable crime and results in the destruction of human civilization. ${ }^{36}$

The teachings of any religion, especially Islam, do not justify acts of terrorism under any pretext. Religion is only a shield to carry out plans and acts of terrorism. However, most of the recruitment of terrorist members is based on religious doctrine, making them believe that their deeds are a sacred mission that can deliver them to God's blessing. ${ }^{37}$

32 Widyaningrum and Dugis, "Terorisme Radikalisme Dan Identitas Keindonesiaan."

33 Muh Wajdi, “Islam Dan Radikalisme (Mengurai Makna Terorisme)” (2017).

34 I Mohammed, "De-Radicalisation and Humanitarianism in Indonesia," Social Sciences 10, no. 3 (2021): 1-17, https://www.scopus.com/inward/record.uri?eid=2s2.0-

$85102570665 \&$ doi $=10.3390 \% 2 F$ socsci10030087\&partnerID $=40 \&$ md5=286b44129019b91 8821b3ab5f9c490bf.

35 U Sumbulah, "Preventing Radicalism by Family and Civil Society Organizations in Indonesia," Pertanika Journal of Social Sciences and Humanities 27, no. 1 (2019): 391-403, https://www.scopus.com/inward/record.uri?eid=2-s2.085072395321\&partnerID=40\&md5=edfcbcdb935f368b4fcc492cf9d6a722.

36 Zulkhaidir, "Islam Dan Terorisme."

37 Firmansyah and Hidayat, "Pendekatan Advokasi Muhammadiyah Dalam Penanganan Terorisme Di Indonesia." 
The acts of terrorism in Indonesia must furthermore have disturbed the peace and tranquility of its people. Even so, the government does not easily eradicate these acts. The development of terrorism in Indonesia shows the weak condition of the state and the absence of the state apparatus's role in maintaining defense and security. ${ }^{38}$ Acts of terror continue to occur in Indonesia with a different number of cases every year.

By involving various actors, including politicians, religious leaders, people in business, and other community leaders, radicalism is increasingly being ordained as the only way to make Indonesia change for the better (Wajdi 2017). Various religious adages were also called on the altar of radicalization to ignite public emotion, especially among a group of people affiliated with this movement. Therefore, although Indonesia has caught the world's attention with the rampant cases of terrorism, at the same time, terrorists are recruiting militant people to make their goal come true and in the name of jihad, they conceal their evil plans. ${ }^{39}$

The visualization of terrorism cases in Indonesia can be seen in Figure 1 below;

38 N G Rogozhina, "The struggle against islamic terrorism in southeast asia," World Economy and International Relations 64, no. 8 (2020): 27-36, https:/ / www.scopus.com/inward/ record.uri?eid=2-s2.085090638343\&doi $=10.20542 \%$ 2F0131-2227-2020-64-8-2736\&partnerID=40\&md5=efc58c71c00d5950be2deba5ba32f897.

39 Mohammed, "De-Radicalisation and Humanitarianism in Indonesia." 


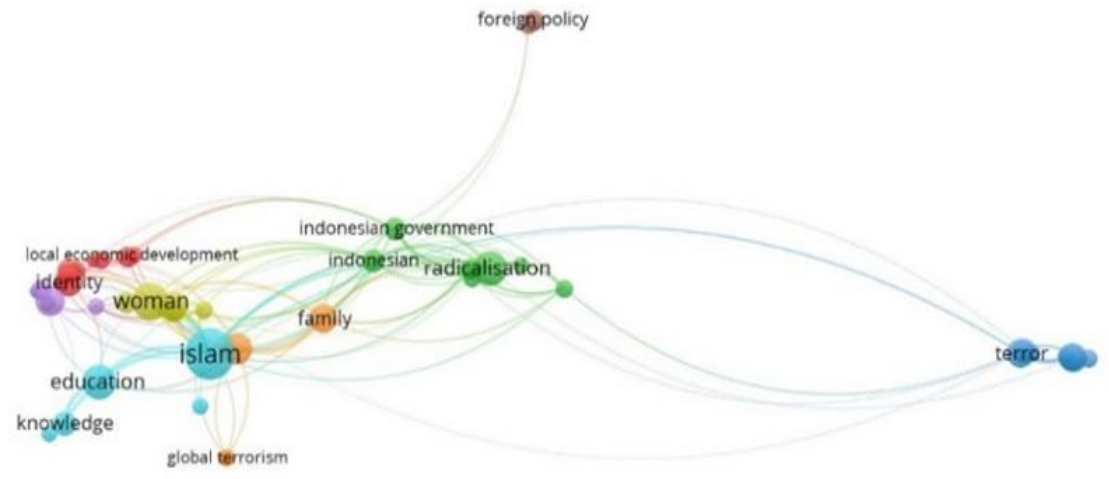

\& vosviewer

\section{Figure 1. The Root of Terrorism Visualization in Indonesia}

The Figure 1 shows an apparent correlation between terrorism, radicalism, and religion. Islam is the most prominent item that has a relationship with terrorism. Furthermore, literature review data processed with VOSviewer reveals that women also have the most intersecting relationship with Islam and education affecting Indonesia's development of terrorism cases. VOSviewer organizes them into 8 groups based on keywords like terrorism, situations, factors, causes, country, product, countermeasures, and Indonesia. It can be seen in the table of contents for each cluster below:

\begin{tabular}{|c|c|}
\hline $\begin{array}{c}\text { Cluster 1 } \\
\text { (9 Items) }\end{array}$ & $\begin{array}{c}\text { Expressions, Identity, Local Development, Local } \\
\text { Government, National Identity, Pesantren, Responder, } \\
\text { Securitization, Terrorism Issue }\end{array}$ \\
\hline $\begin{array}{c}\text { Cluster 2 } \\
\text { (8 Items) }\end{array}$ & $\begin{array}{c}\text { Civil Society Organization, Indonesian, Indonesian } \\
\text { Government, Moderate Islam, Muslim Population, } \\
\text { Radicalization, Radicalization Program, Youth } \\
\text { Radicalization. }\end{array}$ \\
\hline $\begin{array}{c}\text { Cluster 3 } \\
\text { (7 Items) }\end{array}$ & $\begin{array}{c}\text { Indonesian Millennial Muslim, Jihad, Radical, Terror, } \\
\text { Terror Attack, Terrorist Group, Terrorist Organization. }\end{array}$ \\
\hline $\begin{array}{c}\text { Cluster 4 } \\
\text { (6 Items) }\end{array}$ & Democracy, Islamism, Nationalism, Niqabi, Niqabis, \\
\end{tabular}




\begin{tabular}{|c|c|}
\hline $\begin{array}{c}\text { Cluster 5 } \\
\text { (5 Items) }\end{array}$ & $\begin{array}{c}\text { Counter-terrorism, Domestic Security Dilemma, Human } \\
\text { Right, Political Right, Religious Leader. }\end{array}$ \\
\hline $\begin{array}{c}\text { Cluster 6 } \\
\text { (5 Items) }\end{array}$ & Education, Indonesian Muslim, Islam, Knowledge, \\
Terrorism Industry.
\end{tabular}

Table 1. VOSviewer Cluster Analysis

Table 1 of the bibliometric analysis using VOSviewer shows a relationship between Islamic views, Islamic teachings, terrorism acts, and radicalism movements in Indonesia. This movement can cause terror mainly because of its distinctive opinions and understanding of democracy and nationalism. ${ }^{40}$ Muslim population in Indonesia the terrorist groups freely oppose democracy using the jihad concept. ${ }^{41}$ They base their action on the strong will to fight for Islam using the jihad so that they tend to justify any means to realize it including even though using violence such as physical attacks and bombings. ${ }^{42}$

The cluster analysis above also shows how women's presence becomes a critical spotlight. Women and the niqab are synonymous with the religious radicalism movement although it is generally believed that not all women with the niqab are terrorists. This situation seems to explain the relationship between religiosity and terrorist behavior in Indonesia. General understanding of the Indonesian terrorism act needs to be put in the context of the larger terrorism

40 Windiani, "Peran Indonesia Dalam Memerangi Terorisme."

41 A Fenton and D Price, "ISIS, Jihad and Indonesian Law: Legal Impacts of the January 2016 Jakarta Terrorist Attacks," Issues in Legal Scholarship 14, no. 1 (2016): 126, https://www.scopus.com/inward/record.uri?eid=2-s2.085002574593\&doi=10.1515\%2Fils-20160255\&partnerID=40\&md5=16c2bd387b78347b2701d71d90bbeca8.

42 I E Putra et al., "Tackling Islamic Terrorism and Radicalism in Indonesia by Increasing the Sense of Humanity and Friendship," in Violent Extremism: Breakthroughs in Research and Practice (Persada Indonesia University, Indonesia: IGI Global, 2018), 280-301, https://www.scopus.com/inward/record.uri?eid=2-s2.085059711271\&doi $=10.4018 \% 2 F 978-1-5225-7119$ -

3.ch016\&partnerID $=40 \& m d 5=f d 2 f 86 e e f b 01 a c 5 d f 0 c 5 f b c 04165 d a 00$. 
movement. ${ }^{43}$ These acts of violence are typically motivated by specific thoughts or justification that they claim as religious teachings. Other terrorism movements do not have a direct relation to certain spiritual teachings 44 like terrorism act occurring because of political, and cultural motivations. ${ }^{45}$ Unfair and non-ideal situations such as unfair treatment, discrimination, and marginalization in the political and cultural fields often encourage the occurrence or development of terrorism as well. ${ }^{46}$ Thus, whether driven by a belief in certain religious propositions or other motivations, the terrorism movement aims to defend a specific value be it religion, justice, or cultural ones. ${ }^{47}$

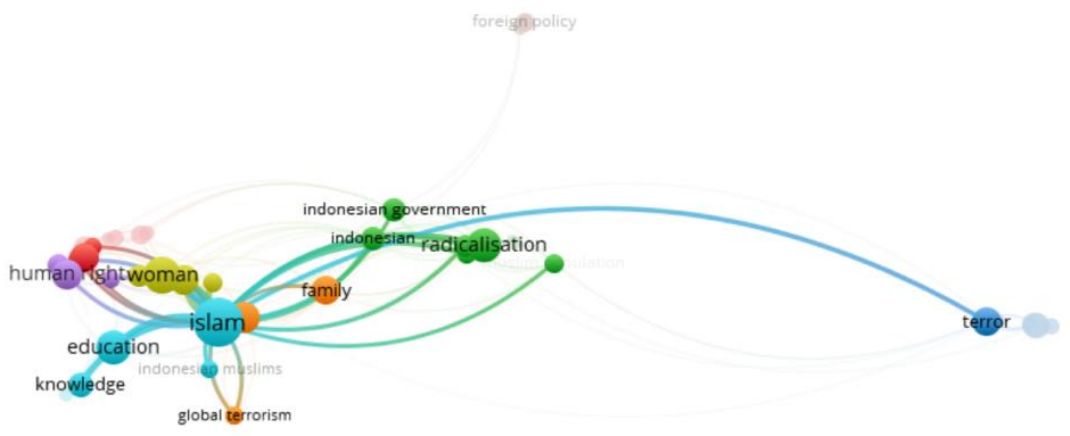

Figure 2. The Relation Between Terrorist and Islam

Meanwhile, Figure 2 above shows how on one hand, religion is a place where people find peace, depth of life, and firm hope but on the other hand, it is often associated with violence and various conflict

43 Faiqah and Pransiska, "Islamic Radicalism Vs Islamic Moderation: Efforts to Build the Face of Peaceful Indonesian Islam."

44 Firmansyah and Hidayat, "Pendekatan Advokasi Muhammadiyah Dalam Penanganan Terorisme Di Indonesia."

45 Zulkhaidir, "Islam Dan Terorisme."

46 Amra Sabic-El-Rayess, "Epistemological Shifts in Knowledge and Education in Islam: A New Perspective on the Emergence of Radicalization amongst Muslims," International Journal of Educational Development 73, no. November 2019 (2020): 102148, https://doi.org/10.1016/j.ijedudev.2019.102148.

47 Nakissa, "Security, Islam, and Indonesia An Anthropological Analysis of Indonesiaâs National Counterterrorism Agency." 
incidents. ${ }^{48}$ Specific religious mechanisms are vulnerable to violence and conflict. ${ }^{49}$ This symptom particularly can occur when love for a particular value system develops to have political implications. ${ }^{50}$ By cornering other people for their religious or ethnic ownership, acts of hatred are commonly taking place in the form of resistance, especially targetting ideas and institutions that are considered contrary to their beliefs. 51

\section{Factors Causing the Growing of Terrorism in Indonesia}

A terrorist movement is a symptom of a revival in fighting injustice, oppression, and slander committed by some parts of the local community and the world against other parts of society. Based on the 51 literature review documents. The image below is the result of the word frequency analysis using Nvivo from the 51 papers.

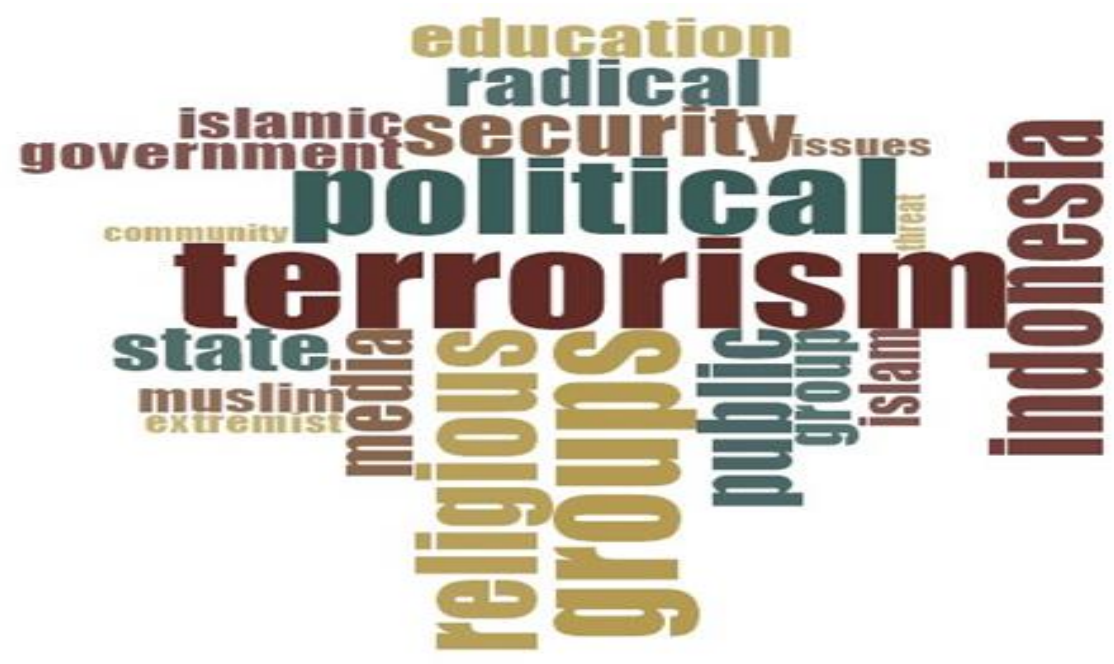

Figure 3. Word Frequency of Terrorism in Indonesia

${ }^{48}$ Dzuhayatin, "Islamism and Nationalism among Niqabis Women in Egypt and Indonesia."

49 Widyaningrum and Dugis, "Terorisme Radikalisme Dan Identitas Keindonesiaan."

50 Priyanto, Dermawan, and Runturambi, "Islah as the Key Success of Terrorist Disengagement Process in Indonesia."

51 Sabic-El-Rayess, "Epistemological Shifts in Knowledge and Education in Islam: A New Perspective on the Emergence of Radicalization amongst Muslims." 
The literature analysis results based on the theme show that terrorism is the most highlighted issue. Terrorist groups in Indonesia can be fairly associated with radical groups. It turns out that both are found to overlap with the religion believed by the majority of Indonesia's population, namely Islam. This also shares the same with most of international society, especially the Western world with democratic ideology, who oppose Islam because considering it as a totalitarian ideology that rejects democracy, personal freedom, and religion 52 .

The assumption leads to a general perspective to always associate terrorism with Islam. ${ }^{53}$ Acts of terrorism are widely believed to contain political elements that use unhealthy forces, including religious weapons. ${ }^{54}$ Religion, therefore, becomes fragile because its adherents can do anything against the applicable law by hijacking religion itself. ${ }^{55}$ Religion, for instance, teaches people to humanize people so that any actions that harm and destroy man's civilization are not original religious teachings. ${ }^{56}$

\section{Mapping of Terrorism Issues from the Aspects of the Islamic Movement}

Religion, on the one hand, is a place where people can find serenity, meaning, and steadfast hope; on the other hand, religion is frequently associated with violence and many conflicts. When it comes to violence and war, religious mechanisms are particularly vulnerable. ${ }^{57}$.

When a person's love for a certain set of values gets politicized, it can turn violent and cause conflict. When individuals feel cornered for their religious or ethnic ownership, especially when it comes to components of concepts and institutions that are seen antagonistic to

\footnotetext{
52 Mayur Suresh, “The Social Life of Technicalities: 'Terrorist' Lives in Delhi's Courts," Contributions to Indian Sociology 53, no. 1 (2019): 72-96.

53 Wajdi, "Islam Dan Radikalisme (Mengurai Makna Terorisme)."

54 Mustofa, "TERORISME: ANTARA AKSI DAN REAKSI (Gerakan Islam Radikal Sebagai Respon Terhadap Imperealisme Modern)."

55 Affan, "The Threat of Is Proxy Warfare on Indonesian Millennial Muslims."

${ }^{56}$ Dzuhayatin, "Islamism and Nationalism among Niqabis Women in Egypt and Indonesia."

57 Widyaningrum and Dugis, "Terorisme Radikalisme Dan Identitas Keindonesiaan."
} 
their beliefs, acts of hatred take the form of resistance and resistance. The core reasons for mass violence are typically rejection and hatred. Efforts to build value systems and points of view that refer to specific ideological levels will strengthen the foundation of belief in the superiority of certain ideologies in the end 58 .

Terrorism is a violation of human life's principles, with terrorism movements originating as a result of social injustice and a lack of understanding of religious law's foundation, the scriptures. Terrorist organizations expand in size as a result of individual group interests and the permission of powerful countries such as the United States and Israel to spread their wings of power or national interests. Terrorists who are captured or executed frequently claim to be fighting for Jihad fi sabilillah, despite the fact that their actions violate religious values, particularly Islamic ones. Murder is prohibited in the Koran unless the victim commits a severe crime that results in the annihilation of human civilization ${ }^{59}$.

Indonesia has caught the world's attention with the rampant cases of terrorism, and terrorists are recruiting militant people to be targeted to smooth their desires and goals ${ }^{60}$. In the name of Jihad, they concealed their evil plans ${ }^{61}$. The teachings of any religion, especially Islam, do not justify acts of terrorism under any pretext. Religion is only a shield to carry out plans and acts of terrorism. Every recruitment of terrorist members is based on religious doctrine, making them believe that their deeds are a sacred mission that can deliver them to the Lord's Ridho 62

Initially, Islam in Indonesia was highly praised for its tolerance.63 However, the greatness of this reputation has been

58 Firmansyah and Hidayat, "Pendekatan Advokasi Muhammadiyah Dalam Penanganan Terorisme Di Indonesia."

59 Zulkhaidir, "Islam dan Terorisme."

60 Windiani, "Peran Indonesia dalam Memerangi Terorisme."

61 A J Fenton, "Faith, Intolerance, Violence and Bigotry: Legal and Constitutional Issues of Freedom of Religion in Indonesia," Journal of Indonesian Islam 10, no. 2 (2016): 181-212, https://www.scopus.com/inward/record.uri?eid=2-s2.085020534637\&doi=10.15642\%2FJIIS.2016.10.2.181-

212\&partnerID=40\&md5=1ea76536c2fb91e00e09d978641aa8f1.

62 Wajdi, "Islam Dan Radikalisme (Mengurai Makna Terorisme)."

63 Firmansyah and Hidayat, "Pendekatan Advokasi Muhammadiyah dalam Penanganan Terorisme Di Indonesia." 
damaged by several bloody incidents involving religion as one of the triggering factors. ${ }^{64}$ Slowly but surely, several radical Islamic organizations in Indonesia have made the image of Islam as a terrorist religion. 65 In plain view, many parties suspect that only Islamic groups commit violent acts of terror. ${ }^{66}$ In fact, anyone from any background can potentially commit acts of terror ${ }^{67}$. The majority of terrorist acts are committed by radical Islamic groups as a result of official repression. As a result, they feel arbitrarily treated, discriminated against, and social and political rivalry in the fight for public office in order to sway the ultranationalist extreme Islamic movement from the Middle East. ${ }^{68}$. On the other hand, there are only a few terrorists from different religions and this makes terrorist stigmatization appears mostly in Muslim groups. ${ }^{69}$

\section{E. Factors Causing the Growing Issue of Terrorism in Indonesia}

Terrorism is the most prominent concern, according to the results of the literature study based on the subject (figure 3). Extremist organizations can potentially be labeled as terrorist organizations in Indonesia. Terrorism and extremism in Indonesia are thought to be linked to the majority of the country's population's religion, Islam. Islam is viewed as a totalitarian doctrine that rejects democracy,

64 N Nuraniyah, "Not Just Brainwashed: Understanding the Radicalization of Indonesian Female Supporters of the Islamic State," Terrorism and Political Violence 30, no. 6 (2018): 890-910, https://www.scopus.com/inward/record.uri?eid=2-s2.085049639421\&doi $=10.1080 \% 2$ F09546553.2018.1481269\&partnerID $=40 \& m d 5=85 b 63 b d 1$ $1 \mathrm{afb} 8838 \mathrm{a} 24 \mathrm{fbd} 5 \mathrm{f} 4 \mathrm{c} 33444 \mathrm{~d}$.

65 Affan, "The Threat of Is Proxy Warfare on Indonesian Millennial Muslims."

66 M Haripin, C R Anindya, and A Priamarizki, "The Politics of CounterTerrorism in Post-Authoritarian States: Indonesia's Experience, 1998-2018," Defense and Analysis Arity (2020): 1-25, https:// www.scopus.com/inward/ record.uri?eid=2-s2.0$85088250885 \&$ doi $=10.1080 \%$ 2F14751798.2020.1790807\&partnerID=40\&md5=8918e671 4f1e15dd3eb68807ed75a52c.

67 Faiqah and Pransiska, "Islamic Radicalism Vs Islamic Moderation: Efforts to Build the Face of Peaceful Indonesian Islam."

68 Dzuhayatin, "Islamism and Nationalism among Niqabis Women in Egypt and Indonesia."

69 Rogozhina, "The struggle against islamic terrorism in southeast asia." 
personal freedom, and other religions by the majority of people in democratic Western countries. ${ }^{70}$

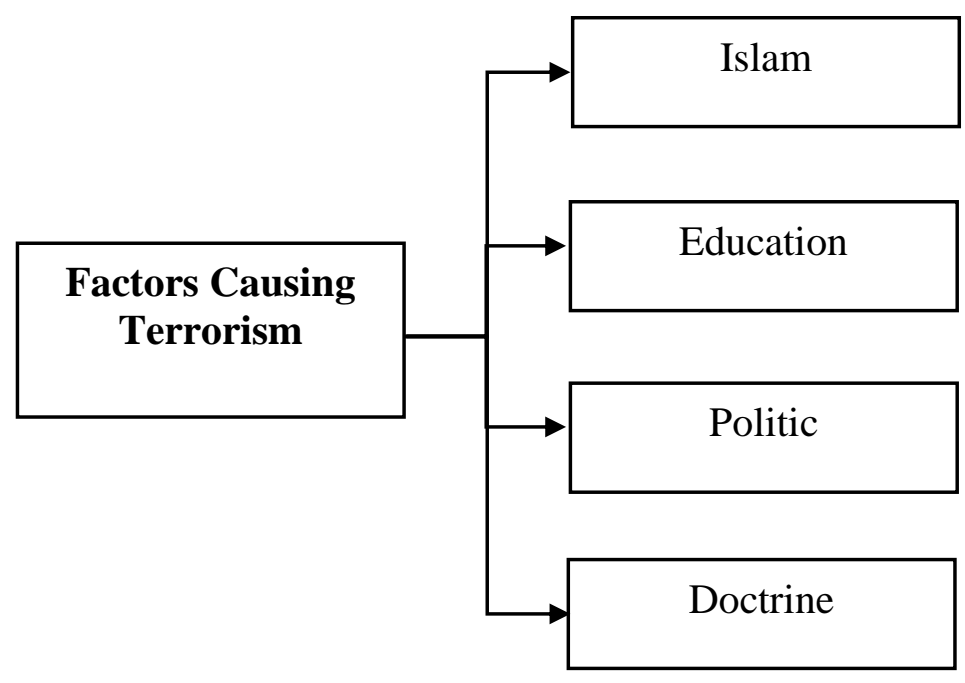

\section{Chart 2. Model Factors Causing the Growing Issue of Terrorism in Indonesia}

Chart 2 shows that terrorism action is widely believed to contain political elements that use violent force, including religious weapons. Religion as believing in power is straightforward because human religion can do things contrary to applicable law. The human being is the reason for humans who always discuss Islam. Acts that harm and damage humans make it a habit of actual religious teachings, even if the adherents are weak. Committing crimes will only cause destruction. This kind of doctrine has resulted in the growth of terrorism issues in Indonesia.

Apart from the ideological motivations mentioned above, two critical factors have contributed to the occurrence of terrorism in Indonesia. First, the weakness of Muslims is caused by the radicalism of the leaders, caused by the moral decline of the Muslim ruling elite. ${ }^{71}$ Radicals accuse the Muslim ruling elites as puppets of the

70 Sahrasad et al., "Indonesian Terrorism: Wahabism and the 'Imagined Caliphate.'”

${ }^{71}$ Ilyas, "Decolonising the Terrorism Industry: Indonesia." 
Western state not only because of the secular system of government but also their government policies which are considered more beneficial to the West. People who do not have any power and cannot solve their problems are the most prospective targets for radicalists to do brainwashing while oppressing and recruiting them. ${ }^{72}$ Second, the objective recognition of radicalism for non-Muslims has reached its peak, both in science and politics. However, their progress used to exploit other nations globally, causing a disharmonious relationship between East (Islam) and West for quite a long time. ${ }^{73}$

Thus, two leading factors that cause radicalism are: First, Muslims historical legacy is conflicted with the regime due to modes of Islamic political oppression in several states. ${ }^{74}$ Second, in a global context, the marginalization of Islamic politics by hegemony in international politics (the Uni ${ }^{75}$ Transnationalism) brought this awareness to Indonesia in Islamic political movements. ${ }^{76}$

Apart from political oppression, the argument of this article is the existence of political pressure. With this argument, radicalism arises because capitalism's excesses create those who do not have access to capital sources. ${ }^{77}$ In the political economy language, this approach is known as the "class approach," meaning that the response to radicalism is a class response against the oligarchic hegemony of capital with the state. ${ }^{78}$

Today, at least three factors can explain the emergence of terror: First is the global constellation of world-class terrorism with Al-Qaeda

72 Handoko, "Analisis Kejahatan Terorisme Berkedok Agama."

73 Nakissa, "Security, Islam, and Indonesia An Anthropological Analysis of Indonesiaâs National Counterterrorism Agency."

74 Dzuhayatin, "Islamism and Nationalism among Niqabis Women in Egypt and Indonesia."

75 J Regan, "The Piracy Terrorism Paradigm: An Interlinking Relationship," Behavioral Sciences of Terrorism and Political Aggression 11, no. 2 (2019): 149-157, https:/ / www.scopus.com/inward/record.uri?eid=2-s2.0-

$85044043006 \&$ doi $=10.1080 \% 2$ F19434472.2018.1445120\&partnerID=40\&md5=987c6a771 cdccb1e8a2969197e433717.

76 Widyaningrum and Dugis, "Terorisme Radikalisme Dan Identitas Keindonesiaan."

77 Nakissa, "Security, Islam, and Indonesia An Anthropological Analysis of Indonesiaâs National Counterterrorism Agency."

78 Widyaningrum and Dugis, "Terorisme Radikalisme Dan Identitas Keindonesiaan." 
and ISIS movements. ${ }^{79}$ Both have become international issues. This condition is associated with the world leader's slanted policy towards Palestine. ${ }^{80}$ Second is the socio disparities in Muslim countries and Western culture expansion which are considered successful to destroy Islamic values through a new paradigm of hedonism and materialism. The third is the Islamic world leaders who are considered powerless and subject to the will of the West. This issue quickly spreads to all corners of the world through virtual networks in both Islamic and Western countries due to many countries' policies that protect rebellion groups who have fled from their respective countries.

\section{Conclusion}

Based on the analysis, some factors that strengthen terrorism in Indonesia include Islamism, politics, education, and doctrine. Furthermore, it is often assumed that the action has political aspects of nonviolent power, including theological weapons. Because human religion has the ability to accomplish things that are against the law, religion might be defined as a belief in power. The human being takes on the role of reason. Acts that harm and harm humanity make it a habit of actual religious doctrines to lead to destruction, even if the adherents are weak. As a result of this concept, terrorism has become more prevalent in Indonesia.

\section{Bibliography}

Achsin, Muhaimin Zulhair. "Culture and Role of Woman in Terrorism in Indonesia. Case Studies: Suicide Bombings in Surabaya and Sibolga." International Journal of Engineering and Advanced Technology 8, no. 5 (2019): 873-876.

79 Firmansyah and Hidayat, "Pendekatan Advokasi Muhammadiyah Dalam Penanganan Terorisme Di Indonesia."

80 A Nakissa, "Security, Islam, and Indonesia An Anthropological Analysis of Indonesiaâs National Counterterrorism Agency," Bijdragen tot de Taal-, Land- en $\begin{array}{lllll}\text { Volkenkunde } & \text { 176, 203-239, }\end{array}$ https://www.scopus.com/inward/record.uri?eid=2-s2.0$85093514803 \&$ doi $=10.1163 \% 2 \mathrm{~F} 22134379$ -

bja10004\&partnerID=40\&md5=c3a4cf6cd8ca7b5a9c2cbe70540cfe96. 
Affan, M. "The Threat of Is Proxy Warfare on Indonesian Millennial Muslims." Indonesian Journal of Islam and Muslim Societies 8, no. 2 (2018): 199-224.

Dzuhayatin, S R. "Islamism and Nationalism among Niqabis Women in Egypt and Indonesia." Indonesian Journal of Islam and Muslim Societies 10, no. 1 (2020): 49-77. https://www.scopus.com/inward/record.uri?eid=2-s2.085086372317\&doi=10.18326\%2Fijims.v10i1.4977\&partnerID=40\&md5=afe1d4cd4042018624cb86a852d450ae.

Dzuhayatin, Siti Ruhaini. "Islamism and Nationalism among Niqabis Women in Egypt and Indonesia." Indonesian Journal of Islam and Muslim Societies 10, no. 1 (2020): 49-77.

Faiqah, Nurul, and Toni Pransiska. "Islamic Radicalism Vs Islamic Moderation: Efforts to Build the Face of Peaceful Indonesian Islam." Al-Fikra: Jurnal Ilmiah Keislaman 17, no. 1 (2018): 33-60. http:// ejournal.uin-suska.ac.id/index.php/alfikra/article/view/5212.

Al Fajri, Muchamad Sholakhuddin. "The Construction of Indonesian Muslims and Islam in Australian Newspapers: A CorpusAssisted Critical Discourse Analysis." Discourse and Interaction 13, no. 1 (2020): 5-24.

Fenton, A J. "Faith, Intolerance, Violence and Bigotry: Legal and Constitutional Issues of Freedom of Religion in Indonesia." Journal of Indonesian Islam 10, no. 2 (2016): 181-212. https:/ / www.scopus.com/inward/record.uri?eid=2-s2.085020534637\&doi=10.15642\%2FJIIS.2016.10.2.181212\&partnerID=40\&md5=1ea76536c2fb91e00e09d978641aa8f1.

Fenton, A, and D Price. "ISIS, Jihad and Indonesian Law: Legal Impacts of the January 2016 Jakarta Terrorist Attacks." Issues in Legal Scholarship 14, no. 1 (2016): 1-26. https:/ / www.scopus.com/inward/record.uri?eid=2-s2.0$85002574593 \&$ doi $=10.1515 \%$ 2Fils-20160255\&partnerID $=40 \& m d 5=16 c 2 b d 387 b 78347 b 2701 d 71 d 90 b b e c a$ 8.

Firmansyah, Firmansyah, and Arief Hidayat. "Pendekatan Advokasi Muhammadiyah Dalam Penanganan Terorisme Di Indonesia." Journal of Political Issues 2, no. 1 (2020): 10-20.

Handoko, Agus. "Analisis Kejahatan Terorisme Berkedok Agama." 
SALAM: Jurnal Sosial dan Budaya Syar-i 6, no. 2 (2019): 155-178.

Haripin, M, C R Anindya, and A Priamarizki. "The Politics of Counter-Terrorism in Post-Authoritarian States: Indonesia's Experience, 1998-2018." Defense and Security Analysis (2020): 125. https://www.scopus.com/inward/record.uri?eid=2-s2.085088250885\&doi $=10.1080 \% 2 F 14751798.2020 .1790807 \&$ partnerI $\mathrm{D}=40 \& \mathrm{md5}=8918 \mathrm{e} 6714 \mathrm{f} 1 \mathrm{e} 15 \mathrm{dd} 3 \mathrm{eb} 68807 \mathrm{ed75a52c}$.

Hatta, M, Zulfan, T Y Afrizal, R Rajamanickam, J Saputra, and Zikri. "The Impact of Terrorism on Indonesia's Economic Stability." International Journal of Innovation, Creativity and Change 9, no. 2 (2019):

https:/ / www.scopus.com/inward/record.uri?eid=2-s2.0-

85080138661\&partnerID=40\&md5=2e646e2b57fd7efa82f3e70e17 8c0156.

Habibi, M. Dani. "Penafsiran Dalil Radikalisme Dan Terorisme Di Indonesia (Interpretasi Ma'na-Cum-Maghza Terhadap Kata Fitnah Dalam Al-Qur'an Surat Al-Baqarah: 190-193)." Al-Dzikra: Jurnal Studi Ilmu Al-Qur'an Dan Al-Hadits, 2019. https:// doi.org/10.24042/al-dzikra.v13i1.3944.

Hwang, J C. Why Terrorists Quit: The Disengagement of Indonesian Jihadists. Why Terrorists Quit: The Disengagement of Indonesian Jihadists. Cornell University Press, 2018. https:/ / www.scopus.com/inward/record.uri?eid=2-s2.085057703681\&partnerID=40\&md5=09ebede66a88a73211ab34959 c33b347.

Ilyas, Mohammed. "Decolonising the Terrorism Industry: Indonesia." Social Sciences 10, no. 2 (2021): 1-16.

Istadiyantha. "Revealing the Propaganda of Communication between the Islamic Fundamentalism Activists of the Middle East and Indonesia." Jurnal Komunikasi: Malaysian Journal of Communication 34, no. 2 (2018): 137-151. https:/ / www.scopus.com/inward/record.uri?eid=2-s2.085049552631\&doi=10.17576\%2FJKMJC-2018-340209\&partnerID=40\&md5=8e186dfcfeb9bac8041d82cf1c3579d4.

Mahfud, Choirul, Niken Prasetyawati, Wahyuddin Wahyuddin, Dyah Satya Yoga Agustin, and Heni Sukmawati. "Religious Radicalism, Global Terrorism and Islamic Challenges in 
Contemporary Indonesia." Jurnal Sosial Humaniora 11, no. 1 (2018): 8.

Mohammed, I. "De-Radicalisation and Humanitarianism in Indonesia." Social Sciences 10, no. 3 (2021): 1-17. https:/ / www.scopus.com/inward/record.uri?eid=2-s2.0$85102570665 \&$ doi $=10.3390 \% 2$ Fsocsci10030087\&partnerID $=40 \& m$ d5=286b44129019b918821b3ab5f9c490bf.

Mohammed, Ilyas. "De-Radicalisation and Humanitarianism in Indonesia." Social Sciences 10, no. 3 (2021): 1-17.

Mufid, A S. "Radikalisme Dan Terorisme Agama, Sebab Dan Upaya Pencegahan." Harmoni 12, no. 1 (2013): 7-17. https://jurnalharmoni.kemenag.go.id/index.php/harmoni/arti cle/view/190.

Mukhtar, Sidratahta. "Strategi Pemerintah Indonesia Menghadapi Terorisme Dalam Era Demokratisasi." Jurnal Reformasi 6, no. 2 (2016): 143-153.

Mustofa, Imam. “TERORISME: ANTARA AKSI DAN REAKSI (Gerakan Islam Radikal Sebagai Respon Terhadap Imperealisme Modern)." Religia 15, no. 1 (2017).

Nakissa, A. "Security, Islam, and Indonesia An Anthropological Analysis of Indonesiaâs National Counterterrorism Agency." Bijdragen tot de Taal-, Land-en Volkenkunde 176, no. 2-3 (2020): 203-239. https://www.scopus.com/inward/record.uri?eid=2s2.0-85093514803\&doi $=10.1163 \% 2 \mathrm{~F} 22134379$ -

bja10004\&partnerID $=40 \& m d 5=c 3 a 4 c f 6 c d 8 c a 7 b 5 a 9 c 2$ cbe70540cfe 96.

Nakissa, Aria. "Security, Islam, and Indonesia An Anthropological Analysis of Indonesiaâs National Counterterrorism Agency." Bijdragen tot de Taal-, Land- en Volkenkunde 176, no. 2-3 (2020): 203-239.

Nuraniyah, N. "Not Just Brainwashed: Understanding the Radicalization of Indonesian Female Supporters of the Islamic State." Terrorism and Political Violence 30, no. 6 (2018): 890-910. https:/ / www.scopus.com/inward/record.uri?eid=2-s2.085049639421\&doi=10.1080\%2F09546553.2018.1481269\&partnerI $\mathrm{D}=40 \& \mathrm{md} 5=85 \mathrm{~b} 63 \mathrm{bd} 11 \mathrm{afb} 8838 \mathrm{a} 24 \mathrm{fbd} 5 \mathrm{f} 4 \mathrm{c} 33444 \mathrm{~d}$.

Priyanto, S, M K Dermawan, and A J S Runturambi. "Islah as the Key Success of Terrorist Disengagement Process in Indonesia." 
Journal of Al-Tamaddun 15, no. 1 (2020): 157-168. https:/ / www.scopus.com/inward/record.uri?eid=2-s2.0$85090700861 \&$ doi $=10.22452 \% 2 F J A T . v o l 15$ no1.11\&partnerID $=40$ \&md5=aceff3c3f769ce5bfeca9244a7decdc5.

Putra, I E, D O Danamasi, A Rufaedah, R S Arimbi, and S Priyanto. "Tackling Islamic Terrorism and Radicalism in Indonesia by Increasing the Sense of Humanity and Friendship." In Violent Extremism: Breakthroughs in Research and Practice, 280-301. Persada Indonesia University, Indonesia: IGI Global, 2018. https:/ / www.scopus.com/inward/record.uri?eid=2-s2.085059711271\&doi $=10.4018 \% 2 F 978-1-5225-7119$ 3.ch016\&partnerID $=40 \& m d 5=$ fd2f86eefb01ac5df0c5fbc04165da0 0 .

Regan, J. "The Piracy Terrorism Paradigm: An Interlinking Relationship." Behavioral Sciences of Terrorism and Political Aggression 11, no. 2 (2019): 149-157. https://www.scopus.com/inward/record.uri?eid=2-s2.085044043006\&doi $=10.1080 \% 2 F 19434472.2018 .1445120 \&$ partnerI $\mathrm{D}=40 \& \mathrm{md} 5=987 \mathrm{c} 6 \mathrm{a771} \mathrm{cdccb1e} 8 \mathrm{a} 2969197 \mathrm{e} 433717$.

Rogozhina, N. "Isis-a threat to security of South-East Asia countries." World Economy and International Relations 60, no. 2 (2016): 5-14. https:/ / www.scopus.com/inward/record.uri?eid=2-s2.0$84997821093 \&$ partnerID $=40 \& m d 5=895 a b e 7 c f 4 c 70$ cf05be865120a $1 \mathrm{~b} 7784$.

Rogozhina, N G. "The struggle against islamic terrorism in southeast asia." World Economy and International Relations 64, no. 8 (2020): 27-36. https://www.scopus.com/inward/record.uri?eid=2s2.0-85090638343\&doi=10.20542\%2F0131-2227-2020-64-8-2736\&partnerID=40\&md5=efc58c71c00d5950be2deba5ba32f897.

Sabic-El-Rayess, Amra. "Epistemological Shifts in Knowledge and Education in Islam: A New Perspective on the Emergence of Radicalization amongst Muslims." International Journal of Educational Development 73, no. November 2019 (2020): 102148. https://doi.org/10.1016/j.ijedudev.2019.102148.

Sahrasad, H, A Maksum, A Chaidar, and T S Ansari. "Indonesian Terrorism: Wahabism and the 'Imagined Caliphate.'" Journal of Social, Political, and Economic Studies 45, no. 1-2 (2020): 31-45. https:// www.scopus.com/inward/record.uri?eid=2-s2.0- 
85082646735\&partnerID=40\&md5=97425d5b8bdd714edc539561 9cb8bc6a.

Sumardewi, Luh. "UPAYA INDONESIA DALAM MEMBERANTAS TERORISME DI ERA SUSILO BAMBANG YUDHOYONO (Pendekatan Tentang Pengeboman Di Wilayah Indonesia)." Jurnal Hubungan Internasional 1, no. 2 (2014): 1-19.

Sukarmi, Hassan Qaqaya, Fransiska A. Susanto, and Rika Kurniaty. "The Qualified Effects Doctrine in the Extraterritorial of Competition Law Application: An Indonesia Perspective." Sriwijaya Law Review. Sriwijaya University, July 2021. https://doi.org/10.28946/SLREV.VOL5.ISS2.1050.PP192-204.

Sumbulah, U. "Preventing Radicalism by Family and Civil Society Organizations in Indonesia." Pertanika Journal of Social Sciences and Humanities 27, no. 1 (2019): 391-403. https:/ / www.scopus.com/inward/record.uri?eid=2-s2.085072395321\&partnerID $=40 \&$ md5 =edfcbcdb935f368b4fcc492cf9 d6a722.

Suresh, Mayur. "The Social Life of Technicalities: 'Terrorist' Lives in Delhi's Courts." Contributions to Indian Sociology 53, no. 1 (2019): 72-96.

Tinggi, Sekolah, Agama Islam, Mulia Astuti, and Media Siber. "Jurnalis Dan Terorisme ( Studi Pustaka Etika Jurnalis Dalam Meliput Dan Memberitakan Kasus Terorisme Di Media Siber )" 1 , no. c (2020).

Umar, Ahmad Rizky Mardhatillah. “Melacak Akar Radikalisme Islam Di Indonesia." Jurnal Ilmu Sosial dan Ilmu Politik 14, no. 2 (2010): 169-186. https://jurnal.ugm.ac.id/jsp/article/view/10935.

Wajdi, Muh. "Islam Dan Radikalisme (Mengurai Makna Terorisme)" (2017).

Widyaningrum, Anastasia Yuni, and Noveina Silviyani Dugis. "Terorisme Radikalisme Dan Identitas Keindonesiaan." Jurnal Studi Komunikasi (Indonesian Journal of Communications Studies) 2, no. 1 (2018): 32-67.

Windiani, Reni. "Peran Indonesia Dalam Memerangi Terorisme." Jurnal Ilmu Sosial 16, no. 2 (2018): 135.

Yumitro, G, D E Kurniawati, Saiman, D M Prasetya, and S M Deniar. "The Modalities and Roles of Local Governments to Face 
Terrorism Issues in Indonesia: The Case Study of Malang Raya Region ." Revista UNISCI 2020, no. 53 (2020): 9-21. https:/ / www.scopus.com/inward/record.uri?eid=2-s2.0$85087831775 \&$ doi $=10.31439 \% 2 F U N I S C I-$ 80\&partnerID=40\&md5=943c5405d2ee062184a5d43c071b48f4. Zulkhaidir, Zulkhaidir. "Islam Dan Terorisme." Jurnal Ilmiah Islam Futura 7, no. 2 (2018): 49. 